\title{
Transactions
}

Cite this: Dalton Trans., 2011, 40, 9276

www.rsc.org/dalton

PAPER

\section{The co-ordination chemistry of tris(3,5-dimethylpyrazolyl)methane manganese carbonyl complexes: Synthetic, electrochemical and DFT studies $\uparrow$}

\author{
Andrew J. Hallett, ${ }^{* a}$ R. Angharad Baber, ${ }^{b}$ A. Guy Orpen $^{b}$ and Benjamin D. Ward ${ }^{a}$ \\ Received 3rd May 2011, Accepted 24th June 2011 \\ DOI: $10.1039 / \mathrm{c1dt10828j}$

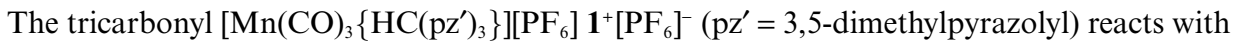 \\ a range of $P$-, $N$ - and $C$-donor ligands, $\mathrm{L}$, in the presence of trimethylamine oxide to give \\ $\left[\mathrm{Mn}(\mathrm{CO})_{2} \mathrm{~L}\left\{\mathrm{HC}\left(\mathrm{pz}^{\prime}\right)_{3}\right\}\right]^{+}\left\{\mathrm{L}=\mathrm{PEt}_{3} \mathbf{3}^{+}, \mathrm{P}(\mathrm{OEt})_{3} \mathbf{4}^{+}, \mathrm{P}\left(\mathrm{OCH}_{2}\right)_{3} \mathrm{CEt} \mathbf{5}^{+}\right.$, py $\mathbf{6}^{+}, \mathrm{MeCN} \mathbf{7}^{+}, \mathrm{CNBu}^{\mathrm{t}} \mathbf{8}^{+}$and \\ $\left.\mathrm{CNXyl} \mathbf{9}^{+}\right\}$. The complex $\left[\mathrm{Mn}(\mathrm{CO})_{2}\left(\mathrm{PMe}_{3}\right)\left\{\mathrm{HC}\left(\mathrm{pz}^{\prime}\right)_{3}\right\}\right]^{+} \mathbf{2}^{+}$is formed by reaction of $\mathbf{7}^{+}$with $\mathrm{PMe}_{3}$. \\ Complexes $\mathbf{2}^{+}$and $\mathbf{6}^{+}$were structurally characterised by X-ray diffraction methods. Reaction of $7^{+}$with \\ half a molar equivalent of 4,4'-bipyridine gives a purple compound assumed to be the bridged dimer \\ $\left[\left\{\mathrm{HC}\left(\mathrm{pz}^{\prime}\right)_{3}\right\} \mathrm{Mn}(\mathrm{CO})_{2}\left(\mu-4,4^{\prime}-\text { bipy }\right) \mathrm{Mn}(\mathrm{CO})_{2}\left\{\mathrm{HC}\left(\mathrm{pz}^{\prime}\right)_{3}\right\}\right]^{2+} \mathbf{1 0}^{2+}$. The relative electron donating ability \\ of $\mathrm{HC}\left(\mathrm{pz}^{\prime}\right)_{3}$ has been established by comparison with the cyclopentadienyl and tris(pyrazolyl)borate \\ analogues. Cyclic voltammetry shows that each of the complexes undergoes an irreversible oxidation. \\ The correlation between the average carbonyl stretching frequency and the oxidation potential \\ for complexes of $P$ - and $C$-donor ligands is coincident with the correlation observed for \\ $\left[\mathrm{Mn}(\mathrm{CO})_{3-m} \mathrm{~L}_{m}\left(\eta-\mathrm{C}_{5} \mathrm{H}_{5-n} \mathrm{Me}_{n}\right)\right]$. The data for complexes of $N$-donor ligands, however, are not \\ coincident due to the presence of a node (and phase change) between the metal and the \\ $N$-donor in the HOMO of the complex as suggested by preliminary DFT calculations.
}

\section{Introduction}

Poly(pyrazolyl)alkane ligands of the type $\mathrm{R}_{4-n} \mathrm{C}\left(\mathrm{pz}^{x}\right)_{n}(n=2,3$ or 4$)$ are neutral analogues of poly(pyrazolyl)borate anions (Fig. 1). ${ }^{1,2}$ The $\mathrm{HC}\left(\mathrm{pz}^{\prime}\right)_{3}$ ligand is considerably less basic than anionic $\mathrm{Tp}^{-}$or $\mathrm{Cp}^{-}$and may also be considered analogous to $\mathrm{C}_{6} \mathrm{H}_{6}$ as they are both neutral, facially-capping, six-electron donors.
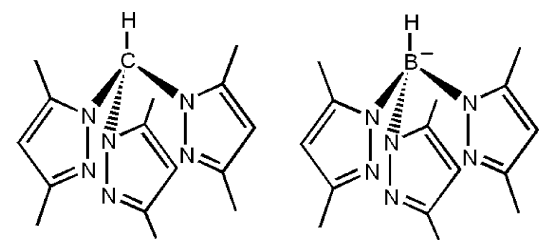

Fig. 1 Neutral tris(3,5-dimethylpyrazolyl)methane $\left[\mathrm{HC}\left(\mathrm{pz}^{\prime}\right)_{3}\right]$ and anionic hydrotris(3,5-dimethylpyrazolyl)borate, $\mathrm{Tp}^{\prime}$, ligands.

Poly(pyrazolyl)borate anions $\left[\mathrm{R}_{4-n} \mathrm{~B}(\mathrm{pz})_{n}\right]^{-}(n=2,3$ or 4$)$ have commonly been used in co-ordination chemistry as their steric and electronic properties are easily modified by changing the number

${ }^{a}$ School of Chemistry, Cardiff University, Main Building, Park Place, Cardiff, CF10 3AT, UK. E-mail: hallettaj@cardiff.ac.uk; Fax: +44 029 20874030; Tel: +4402920879316

${ }^{b}$ School of Chemistry, University of Bristol, Cantock's Close, Bristol, BS8 $1 T S, U K$

$\uparrow$ CCDC reference numbers 822692-822693. For crystallographic data in CIF or other electronic format see DOI: $10.1039 / \mathrm{cldt} 10828 \mathrm{j}$ of, and substituents on, the pyrazolyl rings and the substituents, $\mathrm{R}$, at the boron centre. ${ }^{3-5}$ Tris(pyrazolyl)methane ligands are not as comprehensively studied as their tris(pyrazolyl)borate analogues due to the relative difficulty of preparation. However, in recent years complexes of poly(pyrazolyl)alkane ligands have become more documented ${ }^{6,7}$ partly due to an improved synthesis by Reger et al. ${ }^{8}$

Manganese tricarbonyl complexes have been studied for their CO-releasing properties in photosubstitution reactions. ${ }^{9,10}$ These CORMs (CO-Releasing Molecules) release CO upon UV irradiation and exhibit cytotoxic activity against cancer cells. ${ }^{11,12}$ Substitution of the carbonyls in the manganese complexes with various ligands gives mono and dicarbonyl species. Indeed, the cyclopentadienyl complexes $\left[\mathrm{Mn}(\mathrm{CO})_{3} \mathrm{Cp}^{*}\right]$ and $\left[\mathrm{Mn}(\mathrm{CO})_{3} \mathrm{Cp}\right]$ and the tetrakis(pyrazolyl)borate complex $\left[\mathrm{Mn}(\mathrm{CO})_{3}\left\{(\mathrm{pz}) \mathrm{B}(\mathrm{pz})_{3}\right\}\right]$ undergo photochemical substitution reactions with a range of nucleophilic ligands. ${ }^{13-15}$ However, the degree of substitution depends on the size of the ligand L. An increase in the steric requirements of the pyrazolyl group by the presence of methyl substituents in $\left[\mathrm{Mn}(\mathrm{CO})_{3} \mathrm{Tp}^{\prime}\right]$ leads to mono-substitution only with $\mathrm{P}(\mathrm{OMe})_{3}, \mathrm{P}(\mathrm{OPh})_{3}$ and $\mathrm{PMe}_{3}$ (i.e. only those ligands with small cone angles). Substitution of carbonyls was also reported in the [11] ane- $\mathrm{P}_{2} \mathrm{C}^{\mathrm{NHC}}$ macrocyclic tricarbonyl complexes of Re and Mn using $\mathrm{Me}_{3} \mathrm{NO}{ }^{16,17}$

Manganese tricarbonyl complexes of several functionalised poly(pyrazolyl)alkanes such as tris(pyrazolyl)methane, ${ }^{8,18}$ multitopic ligands, ${ }^{19}$ and [di(pyrazolyl)(2-pyridyl)methyl]aryl 
scorpionates $^{13,20}$ have been reported. However, unlike for the cyclopentadienyl ${ }^{15}$ and poly(pyrazolyl) complexes, ${ }^{14,21}$ there is no literature reporting the substitution of $\mathrm{CO}$.

Here we describe the synthesis of a range of manganese complexes $\left[\mathrm{Mn}(\mathrm{CO})_{2} \mathrm{~L}\left\{\mathrm{HC}\left(\mathrm{pz}^{\prime}\right)_{3}\right\}\right]^{+}\left\{\mathrm{L}=\mathrm{CO}, \mathrm{PMe}_{3}, \mathrm{PEt}_{3}, \mathrm{P}(\mathrm{OEt})_{3}\right.$, $\mathrm{P}\left(\mathrm{OCH}_{2}\right)_{3} \mathrm{CEt}$, py, $\left.\mathrm{MeCN}, \mathrm{CN} t \mathrm{Bu}, \mathrm{CNXyl}\right\}$ in which the pyrazolylmethane ligand occupies three co-ordination sites around the octahedral manganese metal centre. Manganese dicarbonyl complexes were chosen as they are readily obtainable, $\mathrm{CO}$ vibrations can easily be monitored by IR spectroscopy and are oxidised more readily than the analogous tricarbonyl complexes.

\section{Results and discussion}

\section{Synthesis and characterisation of tris(3,5-dimethylpyrazolyl)methane manganese complexes}

The manganese tricarbonyl complex $\left[\mathrm{Mn}(\mathrm{CO})_{3}\left\{\mathrm{HC}\left(\mathrm{pz}^{\prime}\right)_{3}\right\}\right]\left[\mathrm{PF}_{6}\right]$ $\mathbf{1}^{+}\left[\mathrm{PF}_{6}\right]^{-}$was prepared in two stages, by reacting $\left[\mathrm{MnBr}(\mathrm{CO})_{5}\right]$ with tris(3,5-dimethylpyrazolyl)methane and subsequent addition of ammonium hexafluorophosphate. UV irradiation in the presence of various coordinating ligands (phosphines, etc.) did not give the desired mono- or di-substituted manganese products, but led to complete decomposition. However, the neutral tris(pyrazolyl)methane ligand makes complexes such as $\left.\left[\mathrm{Mn}(\mathrm{CO})_{3}\left\{\mathrm{HC}_{(\mathrm{pz}}\right)_{3}\right\}\right]^{+} \mathbf{1}^{+}$more susceptible to nucleophilic attack at $\mathrm{CO}$ than analogous pyrazolylborate complexes. Thus, complex $\mathbf{1}^{+}$does react with various ligands in the presence of trimethylamine oxide to give monosubstituted dicarbonyls (Scheme 1). As with the pyrazolylborate analogue, ${ }^{21}$ there was no reaction between $\left[\mathrm{Mn}(\mathrm{CO})_{3}\left\{\mathrm{HC}\left(\mathrm{pz}^{\prime}\right)_{3}\right\}\right]^{+}$and $\mathrm{PPh}_{3}$ or $\mathrm{PCy}_{3}$ (i.e. phosphines with larger cone angles).

An alternative route to complexes $\mathbf{2}^{+}-\mathbf{6}^{+}$and $\mathbf{8}^{+}-\mathbf{9}^{+}$involved the reaction of $\left[\mathrm{Mn}(\mathrm{CO})_{2}(\mathrm{NCMe})\left\{\mathrm{HC}\left(\mathrm{pz}^{\prime}\right)_{3}\right\}\right]^{+} 7^{+}$with $\mathrm{L}$ in $\mathrm{CH}_{2} \mathrm{Cl}_{2}$. Indeed, the synthesis of $\mathbf{2}^{+}$can only be accomplished by this route. Reaction of $\mathbf{1}^{+}$with $\mathrm{Me}_{3} \mathrm{NO}$ in the presence of $\mathrm{PMe}_{3}$ does not result in substitution, only oxidation of the phosphine. In addition, the reaction of $7^{+}$with half a molar equivalent of $4,4^{\prime}$ bipyridine in $\mathrm{CH}_{2} \mathrm{Cl}_{2}$ yields a moderately soluble purple complex, $\mathbf{1 0}^{\mathbf{2}}$, showing two IR carbonyl stretching bands and is assumed to be $\left[\left\{\mathrm{HC}\left(\mathrm{pz}^{\prime}\right)_{3}\right\}(\mathrm{CO})_{2} \mathrm{Mn}\left(\mu-4,4^{\prime}\right.\right.$-bipy $\left.) \mathrm{Mn}(\mathrm{CO})_{2}\left\{\mathrm{HC}\left(\mathrm{pz}^{\prime}\right)_{3}\right\}\right]\left[\mathrm{PF}_{6}\right]_{2}$ (Fig. 2). Dissolving $\mathbf{1 0}^{2+}$ in acetonitrile results in a purple to yellow

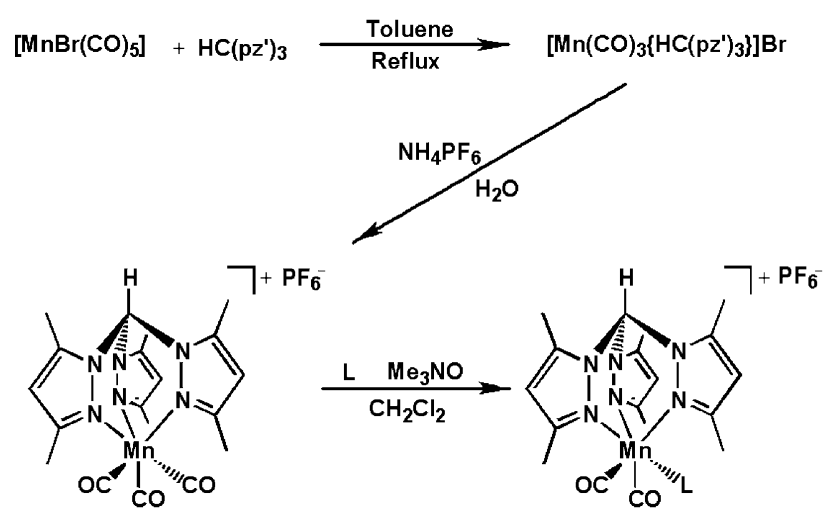

Scheme 1 Synthetic route to $\left[\mathrm{Mn}(\mathrm{CO})_{2} \mathrm{~L}\left\{\mathrm{HC}\left(\mathrm{pz}^{\prime}\right)_{3}\right\}\right]\left[\mathrm{PF}_{6}\right]$.

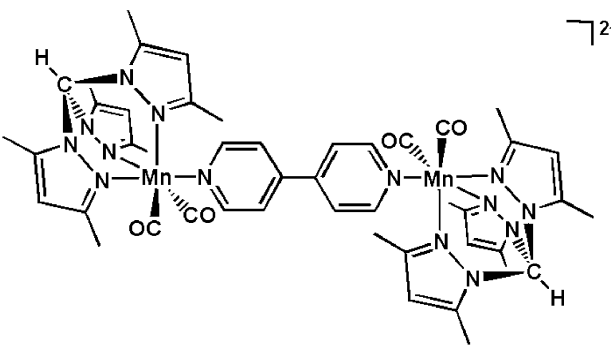

Fig. 2 The proposed structure of $\mathbf{1 0}^{2+}$.

colour change (over $c a$. ten minutes) and an IR carbonyl stretching frequency identical to that of $\left[\mathrm{Mn}(\mathrm{CO})_{2}(\mathrm{NCMe})\left\{\mathrm{HC}\left(\mathrm{pz}^{\prime}\right)_{3}\right\}\right]^{+} \mathbf{7}^{+}$.

Surprisingly, there was no reaction between $7^{+}$and $2,2^{\prime}-$ bipyridine, even in refluxing $\mathrm{CHCl}_{3}$, possibly due to increased steric interactions. Indeed, for the substitution reactions of $\mathbf{1}^{+}$only one carbonyl ligand was substituted in all cases, affording the complexes $3^{+}-\mathbf{1 0}^{+}$. Both the cyclopentadieny $1^{15}$ and pyrazolylborate ${ }^{14,21}$ analogues give mono- and di-substituted complexes. In addition, the use of bidentate ligands such as dppe $\{1,2-$ bis(diphenylphosphino)ethane $\}$ did not induce substitution. This is perhaps not so surprising given that there was also no reaction with $\mathrm{PPh}_{3}$.

Complexes $\mathbf{1}^{+}-\mathbf{1 0}^{2+}$ were characterised by elemental analysis (Table 1), X-ray crystallography in the cases of $\mathbf{2}^{+}$and $\mathbf{6}^{+},{ }^{1} \mathrm{H}$ NMR spectroscopy (except for $\mathbf{1 0}^{\mathbf{2}}$ ), IR spectroscopy (Table 1) and cyclic voltammetry (Table 5).

Table 1 Analytical and IR spectroscopic data for $\left[\mathrm{Mn}(\mathrm{CO})_{2} \mathrm{~L}\left\{\mathrm{HC}\left(\mathrm{pz}^{\prime}\right)_{3}\right\}\right]^{+}$and $\left[\left\{\mathrm{HC}\left(\mathrm{pz}^{\prime}\right)_{3}\right\}(\mathrm{CO})_{2} \mathrm{Mn}\left(\mu-4,4^{\prime}-\mathrm{bipy}\right) \mathrm{Mn}(\mathrm{CO})_{2}\left\{\mathrm{HC}(\mathrm{pz})_{3}\right\}\right]^{2+}$

\begin{tabular}{|c|c|c|c|c|c|c|}
\hline \multirow[b]{2}{*}{ Complex $^{a}$} & \multirow[b]{2}{*}{ Colour } & \multicolumn{3}{|c|}{ Analysis $(\%)^{b}$} & \multicolumn{2}{|l|}{$\mathrm{IR}^{c} / \mathrm{cm}^{-1}$} \\
\hline & & $\mathrm{C}$ & $\mathrm{H}$ & $\mathrm{N}$ & $v(\mathrm{CO})$ & $v(\mathrm{CN})$ \\
\hline$\left[\mathrm{Mn}(\mathrm{CO})_{3}\left\{\mathrm{HC}\left(\mathrm{pz}^{\prime}\right)_{3}\right\}\right]^{+} \mathbf{1}^{+}$ & yellow & $39.4(39.2)$ & $3.7(3.8)$ & $14.3(14.4)$ & $2045,1950(b)$ & - \\
\hline$\left[\mathrm{Mn}(\mathrm{CO})_{2}\left(\mathrm{PMe}_{3}\right)\left\{\mathrm{HC}\left(\mathrm{pz}^{\prime}\right)_{3}\right\}\right]^{+} \mathbf{2}^{+}$ & yellow & $36.6(36.6)$ & $5.0(4.7)$ & $11.9(11.8)^{d}$ & 1945,1866 & - \\
\hline$\left[\mathrm{Mn}(\mathrm{CO})_{2}\left(\mathrm{PEt}_{3}\right)\left\{\mathrm{HC}\left(\mathrm{pz}^{\prime}\right)_{3}\right\}\right]^{+} \mathbf{3}^{+}$ & yellow & $40.9(41.2)$ & $5.3(5.4)$ & $12.0(11.8)^{e}$ & 1942,1864 & - \\
\hline$\left[\mathrm{Mn}(\mathrm{CO})_{2}\left\{\mathrm{P}\left(\mathrm{OEt}_{3}\right)\right\}\left\{\mathrm{HC}\left(\mathrm{pz}^{\prime}\right)_{3}\right\}\right]^{+} \mathbf{4}^{+}$ & yellow & $35.3(35.1)$ & $4.6(4.6)$ & $9.7(9.4)^{f}$ & 1963,1886 & - \\
\hline$\left[\mathrm{Mn}(\mathrm{CO})_{2}\left\{\mathrm{P}\left(\mathrm{OCH}_{2}\right)_{3} \mathrm{CEt}\right\}\left\{\mathrm{HC}\left(\mathrm{pz}^{\prime}\right)_{3}\right\}\right]^{+} \mathbf{5}^{+}$ & yellow & $35.2(35.2)$ & $4.2(4.2)$ & $9.6(9.5)^{f}$ & 1976,1900 & - \\
\hline$\left[\mathrm{Mn}(\mathrm{CO})_{2}(\mathrm{py})\left\{\mathrm{HC}^{\prime}\left(\mathrm{pz}^{\prime}\right)_{3}\right\}\right]^{+} \mathbf{6}^{+}$ & orange & $42.1(41.8)$ & $4.2(4.2)$ & $14.7(14.5)^{e}$ & 1945,1861 & - \\
\hline$\left[\mathrm{Mn}(\mathrm{CO})_{2}(\mathrm{MeCN})\left\{\mathrm{HC}\left(\mathrm{pz}^{\prime}\right)_{3}\right\}\right]^{+} \boldsymbol{7}^{+}$ & orange & $38.4(38.6)$ & $4.2(4.1)$ & $15.2(15.4)^{e}$ & 1960,1877 & - \\
\hline$\left[\mathrm{Mn}(\mathrm{CO})_{2}\left(\mathrm{CNBu}^{t}\right)\left\{\mathrm{HC}\left(\mathrm{pz}^{\prime}\right)_{3}\right\}\right]^{+} \mathbf{8}^{+}$ & yellow & $41.6(41.5)$ & $4.7(4.7)$ & $14.2(14.4)^{e}$ & 1963,1896 & 2136 \\
\hline$\left[\mathrm{Mn}(\mathrm{CO})_{2}(\mathrm{CNXyl})\left\{\mathrm{HC}\left(\mathrm{pz}^{\prime}\right)_{3}\right\}\right]^{+} \mathbf{9}^{+}$ & yellow & $45.2(45.4)$ & $4.0(4.4)$ & $13.2(13.5)^{e}$ & 1964, 1907 & 2106 \\
\hline$\left[\left\{\mathrm{HC}\left(\mathrm{pz}^{\prime}\right)_{3}\right\}(\mathrm{CO})_{2} \mathrm{Mn}\left(\mu-4,4^{\prime}-\text { bipy }\right) \mathrm{Mn}(\mathrm{CO})_{2}\left\{\mathrm{HC}\left(\mathrm{pz}^{\prime}\right)_{3}\right\}\right]^{2+} \mathbf{1 0}^{2+}$ & purple & $41.5(41.8)$ & $4.3(4.0)$ & $14.4(14.5)^{d}$ & 1946,1865 & - \\
\hline
\end{tabular}


Table 2 Carbonyl stretching frequencies of $\left[\mathrm{Mn}(\mathrm{CO})_{3}(\right.$ Ligand $\left.)\right]$ $\left(\right.$ Ligand $=\mathrm{Cp}^{*}, \mathrm{Cp}, \mathrm{Tp}^{\prime}$ and $\mathrm{Tp}$ ) and $\left[\mathrm{Mn}(\mathrm{CO})_{3}\left\{\mathrm{HC}\left(\mathrm{pz}^{\prime}\right)_{3}\right\}\right]\left[\mathrm{PF}_{6}\right] \mathbf{1}^{+}\left[\mathrm{PF}_{6}\right]^{-}$

\begin{tabular}{ll}
\hline Ligand & $v(\mathrm{CO}) / \mathrm{cm}^{-1}$ \\
\hline $\mathrm{Cp}{ }^{*}$ & $2017,1929^{28}$ \\
$\mathrm{Cp}$ & $2028,1947^{26}$ \\
$\mathrm{Tp}^{\prime}$ & $2032,1927^{21}$ \\
$\mathrm{Tp}$ & $2042,1941^{21}$ \\
$\mathrm{HC}\left(\mathrm{pz}^{\prime}\right)_{3}$ & 2045,1950 \\
\hline
\end{tabular}

Table 3 Selected bond lengths $(\AA)$ and angles $\left({ }^{\circ}\right)$ for $\left[\mathrm{Mn}(\mathrm{CO})_{2}\right.$ $\left.\left(\mathrm{PMe}_{3}\right)\left\{\mathrm{HC}\left(\mathrm{pz}^{\prime}\right)_{3}\right\}\right]\left[\mathrm{PF}_{6}\right] \mathbf{2}^{+}\left[\mathrm{PF}_{6}\right]^{-}$and $\left[\mathrm{Mn}(\mathrm{CO})_{2}(\mathrm{py})\left\{\mathrm{HC}\left(\mathrm{pz}^{\prime}\right)_{3}\right\}\right]\left[\mathrm{PF}_{6}\right]$. $2 \mathrm{CH}_{2} \mathrm{Cl}_{2} \mathbf{6}^{+}\left[\mathrm{PF}_{6}\right]^{-} \cdot 2 \mathrm{CH}_{2} \mathrm{Cl}_{2}$

\begin{tabular}{lll}
\hline Bond length (̊)/angle $\left(^{\circ}\right)$ & $\mathbf{2}^{+}\left[\mathrm{PF}_{6}\right]^{-}$ & $\mathbf{6}^{+}\left[\mathrm{PF}_{6}\right]^{-} \cdot 2 \mathrm{CH}_{2} \mathrm{Cl}_{2}$ \\
\hline $\mathrm{Mn}(1)-\mathrm{C}(1)$ & $1.755(8)$ & $1.774(6)$ \\
$\mathrm{Mn}(1)-\mathrm{C}(2)$ & $1.756(8)$ & $1.757(6)$ \\
$\mathrm{Mn}(1)-\mathrm{N}(1)$ & $2.064(5)$ & $2.052(4)$ \\
$\mathrm{Mn}(1)-\mathrm{N}(2)$ & $2.129(5)$ & $2.079(4)$ \\
$\mathrm{Mn}(1)-\mathrm{N}(3)$ & $2.110(5)$ & $2.072(4)$ \\
$\mathrm{C}(1)-\mathrm{O}(1)$ & $1.173(8)$ & $1.166(6)$ \\
$\mathrm{C}(2)-\mathrm{O}(2)$ & $1.167(9)$ & $1.180(6)$ \\
$\mathrm{Mn}(1)-\mathrm{P}(1)$ & $2.293(2)$ & - \\
$\mathrm{Mn}(1)-\mathrm{N}(7)$ & - & $2.048(4)$ \\
$\mathrm{N}(1)-\mathrm{Mn}(1)-\mathrm{N}(2)$ & $80.2(2)$ & $84.1(2)$ \\
$\mathrm{N}(1)-\mathrm{Mn}(1)-\mathrm{N}(3)$ & $82.0(2)$ & $85.3(2)$ \\
$\mathrm{N}(2)-\mathrm{Mn}(1)-\mathrm{N}(3)$ & $90.3(2)$ & $85.7(2)$ \\
$\mathrm{C}(1)-\mathrm{Mn}(1)-\mathrm{C}(2)$ & $84.4(4)$ & $86.3(2)$ \\
$\mathrm{N}(2)-\mathrm{Mn}(1)-\mathrm{C}(2)$ & $174.5(3)$ & $177.9(2)$ \\
$\mathrm{N}(3)-\mathrm{Mn}(1)-\mathrm{C}(1)$ & $176.2(3)$ & $179.3(2)$ \\
$\mathrm{N}(1)-\mathrm{Mn}(1)-\mathrm{P}(1)$ & $169.0(2)$ & - \\
$\mathrm{C}(1)-\mathrm{Mn}(1)-\mathrm{P}(1)$ & $90.0(3)$ & - \\
$\mathrm{C}(2)-\mathrm{Mn}(1)-\mathrm{P}(1)$ & $93.1(3)$ & - \\
$\mathrm{N}(1)-\mathrm{Mn}(1)-\mathrm{N}(7)$ & - & $169.3(2)$ \\
$\mathrm{C}(1)-\mathrm{Mn}(1)-\mathrm{N}(7)$ & - & $93.0(2)$ \\
$\mathrm{C}(2)-\mathrm{Mn}(1)-\mathrm{N}(7)$ & - & $94.2(2)$ \\
\hline
\end{tabular}

Table 4 Crystal and refinement data for $\left[\mathrm{Mn}(\mathrm{CO})_{2}\left(\mathrm{PMe}_{3}\right)\{\mathrm{HC}-\right.$ $\left.\left.\left(\mathrm{pz}^{\prime}\right)_{3}\right\}\right]\left[\mathrm{PF}_{6}\right] \quad \mathbf{2}^{+}\left[\mathrm{PF}_{6}\right]^{-}$and $\left[\mathrm{Mn}(\mathrm{CO})_{2}(\mathrm{py})\left\{\mathrm{HC}\left(\mathrm{pz}^{\prime}\right)_{3}\right\}\right]\left[\mathrm{PF}_{6}\right] \cdot 2 \mathrm{CH}_{2} \mathrm{Cl}_{2}$ $\mathbf{6}^{+}\left[\mathrm{PF}_{6}\right]^{-} \cdot 2 \mathrm{CH}_{2} \mathrm{Cl}_{2}$

\begin{tabular}{|c|c|c|}
\hline Complex & $\mathbf{2}^{+}\left[\mathrm{PF}_{6}\right]^{-}$ & $\mathbf{6}^{+}\left[\mathrm{PF}_{6}\right]^{-} \cdot 2 \mathrm{CH}_{2} \mathrm{Cl}_{2}$ \\
\hline Formula & $\mathrm{C}_{21} \mathrm{H}_{31} \mathrm{~F}_{6} \mathrm{MnN}_{6} \mathrm{O}_{2} \mathrm{P}_{2}$ & $\mathrm{C}_{25} \mathrm{H}_{31} \mathrm{Cl}_{4} \mathrm{~F}_{6} \mathrm{MnN}_{7} \mathrm{O}_{2} \mathrm{P}$ \\
\hline Formula weight & 630.40 & 803.28 \\
\hline$T / \mathrm{K}$ & $173(2)$ & 173(2) \\
\hline Crystal system & Orthorhombic & Monoclinic \\
\hline Space group & $P 2{ }_{1} 2_{1} 2_{1}$ & $P 2_{1} / c$ \\
\hline$a / \AA$ & $12.6906(7)$ & $12.5498(18)$ \\
\hline$b / \AA$ & $12.9537(7)$ & $14.150(2)$ \\
\hline$c / \AA$ & $17.4956(10)$ & $19.981(3)$ \\
\hline$\alpha\left(^{\circ}\right)$ & 90 & 90 \\
\hline$\beta\left(^{\circ}\right)$ & 90 & $100.070(3)$ \\
\hline$\gamma\left({ }^{\circ}\right)$ & 90 & 90 \\
\hline$V / \AA^{3}$ & $2876.1(3)$ & $3493.6(9)$ \\
\hline$Z$ & 4 & 4 \\
\hline$\mu / \mathrm{mm}^{-1}$ & 0.639 & 0.797 \\
\hline Reflections collected & 13045 & 18345 \\
\hline $\begin{array}{l}\text { Independent reflections } \\
\left(R_{\text {int }}\right)\end{array}$ & $4118(0.0489)$ & $6145(0.0839)$ \\
\hline $\begin{array}{l}\text { Final } R 1[I>2 \sigma(I)] \text { : } \\
R_{1}, w R_{2}\end{array}$ & $0.0642,0.1493$ & $0.0621,0.1434$ \\
\hline
\end{tabular}

\section{NMR spectroscopy}

The ${ }^{1} \mathrm{H}$ NMR spectrum of $\mathbf{1}^{+}$shows three equivalent pyrazolyl rings implying $C_{3 \mathrm{~V}}$ symmetry. However, for complexes $\mathbf{2}^{+}-\mathbf{9}^{+}$each
Table 5 Electrochemical data for $\left[\mathrm{Mn}(\mathrm{CO})_{2} \mathrm{~L}\left\{\mathrm{HC}\left(\mathrm{pz}^{\prime}\right)_{3}\right\}\right]^{+} \mathbf{1}^{+}-\mathbf{9}^{+}$and $\left[\left\{\mathrm{HC}\left(\mathrm{pz}^{\prime}\right)_{3}\right\}(\mathrm{CO})_{2} \mathrm{Mn}\left(\mu-4,4^{\prime} \text {-bipy }\right) \mathrm{Mn}(\mathrm{CO})_{2}\left\{\mathrm{HC}\left(\mathrm{pz}^{\prime}\right)_{3}\right\}\right]^{2+} \mathbf{1 0}^{2+}$ in $\mathrm{CH}_{2} \mathrm{Cl}_{2}$ at a platinum electrode

\begin{tabular}{|c|c|}
\hline Complex & $E_{\mathrm{p}}{ }^{\mathrm{ox}}(\mathrm{V})^{a}$ \\
\hline $\left.\mathrm{Mn}(\mathrm{CO})_{3}\left\{\mathrm{HC}\left(\mathrm{pz}^{\prime}\right)_{3}\right\}\right]^{+} \mathbf{1}^{+}$ & 1.11 \\
\hline$\left[\mathrm{Mn}(\mathrm{CO})_{2}\left(\mathrm{PMe}_{3}\right)\left\{\mathrm{HC}\left(\mathrm{pz}^{\prime}\right)_{3}\right\}\right]^{+} \mathbf{2}^{+}$ & 0.38 \\
\hline$\left[\mathrm{Mn}(\mathrm{CO})_{2}\left(\mathrm{PEt}_{3}\right)\left\{\mathrm{HC}\left(\mathrm{pz}^{\prime}\right)_{3}\right\}\right]^{+} \mathbf{3}^{+}$ & 0.37 \\
\hline$\left[\mathrm{Mn}(\mathrm{CO})_{2}\left\{\mathrm{P}\left(\mathrm{OEt}_{3}\right)\right\}\left\{\mathrm{HC}^{\prime}\left(\mathrm{pz}^{\prime}\right)_{3}\right\}\right]^{+} \mathbf{4}^{+}$ & 0.50 \\
\hline$\left[\mathrm{Mn}(\mathrm{CO})_{2}\left\{\mathrm{P}\left(\mathrm{OCH}_{2}\right)_{3} \mathrm{CEt}\right\}\left\{\mathrm{HC}\left(\mathrm{pz}^{\prime}\right)_{3}\right\}\right]^{+} \mathbf{5}^{+}$ & 0.69 \\
\hline$\left[\mathrm{Mn}(\mathrm{CO})_{2}(\mathrm{py})\left\{\mathrm{HC}\left(\mathrm{pz}^{\prime}\right)_{3}\right\}\right]^{+} \mathbf{6}^{+}$ & 0.13 \\
\hline$\left[\mathrm{Mn}(\mathrm{CO})_{2}(\mathrm{MeCN})\left\{\mathrm{HC}\left(\mathrm{pz}^{\prime}\right)_{3}\right\}\right]^{+} \mathbf{7}^{+}$ & 0.21 \\
\hline$\left[\mathrm{Mn}(\mathrm{CO})_{2}\left(\mathrm{CNBu}^{\prime}\right)\left\{\mathrm{HC}\left(\mathrm{pz}^{\prime}\right)_{3}\right\}\right]^{+} \mathbf{8}^{+}$ & 0.57 \\
\hline$\left[\mathrm{Mn}(\mathrm{CO})_{2}(\mathrm{CNXyl})\left\{\mathrm{HC}\left(\mathrm{pz}^{\prime}\right)_{3}\right\}\right]^{+} \mathbf{9}^{+}$ & 0.68 \\
\hline$\left[\left\{\mathrm{HC}\left(\mathrm{pz}^{\prime}\right)_{3}\right\}(\mathrm{CO})_{2} \mathrm{Mn}\left(\mu-4,4^{\prime}\right.\right.$-bipy $) \mathrm{Mn}($ & 0.68 \\
\hline
\end{tabular}

${ }^{a}$ Potentials are calibrated $v s .\left[\mathrm{Fe}\left(\eta^{5}-\mathrm{C}_{5} \mathrm{H}_{5}\right)_{2}\right]($ at $0.00 \mathrm{~V})$ or $\left[\mathrm{Fe}\left(\eta^{5}-\mathrm{C}_{5} \mathrm{Me}_{5}\right)_{2}\right]$ (at $-0.55 \mathrm{~V}$ ).

of the signals for the pyrazolyl protons is split into two, in a $2: 1$ ratio, due to the two rings trans to $\mathrm{CO}$ and one trans to $\mathrm{L}$. The methyl substituents on the pyrazolyl rings also give two signal in the same ratio (see experimental). It was not possible to obtain a well resolved ${ }^{1} \mathrm{H}$ NMR spectrum of $\mathbf{1 0}^{2+}$ due to its insolubility (in a range of solvents). The $\left[\mathrm{BPh}_{4}\right]^{-}$salt of $\mathbf{1 0}^{2+}$ was also insufficiently soluble to provide a useful spectrum.

The ${ }^{31} \mathrm{P}$ NMR spectra of $\mathbf{2}^{+}-\mathbf{5}^{+}$were either very broad or did not show a signal for the phosphine/phosphite ligand, probably due to the quadrupolar nature of the manganese centre. Each complex did, however, show a septet at $c a$. $-145 \mathrm{ppm}$ for the $\left[\mathrm{PF}_{6}\right]^{-}$ion.

\section{IR spectroscopy}

The IR spectrum of $\mathbf{1}^{+}\left[\mathrm{PF}_{6}\right]^{-}$shows two carbonyl stretching absorptions, at 2045 and $1950 \mathrm{~cm}^{-1}$. The lower energy band is broad, consistent with a tricarbonyl complex with $C_{3 \mathrm{v}}$ symmetry. These absorptions are very similar in energy to those reported for the analogous triflate salt, at 2044 and $1949 \mathrm{~cm}^{-1}, 8$ and the rhenium complex $\left[\operatorname{Re}(\mathrm{CO})_{3}\left\{\mathrm{HC}\left(\mathrm{pz}^{\prime}\right)_{3}\right\}\right] \mathrm{Br}$, at 2036 and $1930 \mathrm{~cm}^{-1} .{ }^{22} \mathrm{Com}-$ plexes $\mathbf{2}^{+} \mathbf{9}^{+}$and $\mathbf{1 0}^{2+}$ each show two strong IR carbonyl bands consistent with $C_{2 V}$ symmetry. These vary in energy by $46 \mathrm{~cm}^{-1}$ depending on the electron-donating/accepting ability of the coligand. Complexes $\mathbf{8}^{+}$and $\mathbf{9}^{+}$also show a $\mathrm{CN}$ stretch due to the isocyanide ligands (Table 1). Frequencies for the complexes $\mathbf{2}^{+}$ $\mathbf{9}^{+}$increase in the order $\mathrm{L}=\mathrm{PEt}_{3}<$ py $<\mathrm{PMe}_{3}<\mathrm{MeCN}<$ $\mathrm{P}(\mathrm{OEt})_{3}<t \mathrm{BuNC}<\mathrm{XylNC}<\mathrm{P}\left(\mathrm{OCH}_{2}\right)_{3} \mathrm{CEt}$, consistent with accepted trends in electron donor and acceptor ability for these ligands. ${ }^{23-25}$

The relative electron-donating ability of the ligands $T p^{\prime}, T p$, $\mathrm{Cp}^{*}$ and $\mathrm{Cp}$ varies with metal, oxidation state and co-ligands. ${ }^{26,27}$ For Group 7 carbonyl complexes there is some ambiguity as to the trends in electron donating ability of $\mathrm{Cp}$ and $\mathrm{Tp}$ type ligands. ${ }^{26}$ However, for manganese, in general the $\mathrm{Cp}$ ligands are more electron donating than the Tp ligands. The carbonyl stretching frequency for the pyrazolylmethane complex is greater than that observed for the pyrazolylborate and cyclopentadienyl complexes (Table 2). However, the complexes of $\mathrm{Cp}^{*}, \mathrm{Cp}, \mathrm{Tp}^{\prime}$ and $\mathrm{Tp}$ are neutral whereas $\mathbf{1}^{+}$is cationic. The positive charge on the metal reduces back donation to the $\mathrm{CO}$ ligands thus, increasing 
$v(\mathrm{CO})$. Overall, the electron-donating ability of the ligands for manganese(I) complexes follows the trend:

$$
\mathrm{Cp}^{*}>\mathrm{Cp} \approx \mathrm{Tp}^{\prime}>\mathrm{Tp}>\mathrm{HC}\left(\mathrm{pz}^{\prime}\right)_{3}
$$

\section{Solid state structural analysis}

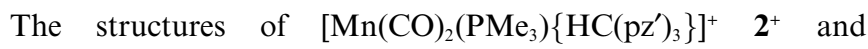
$\left[\mathrm{Mn}(\mathrm{CO})_{2}(\mathrm{py})\left\{\mathrm{HC}\left(\mathrm{pz}^{\prime}\right)_{3}\right\}\right]^{+} \mathbf{6}^{+}$as $\left[\mathrm{PF}_{6}\right]^{-}$salts were determined by X-ray crystallography (Tables 3 and 4). Crystals of each were grown by allowing $n$-hexane to diffuse slowly into a concentrated $\mathrm{CH}_{2} \mathrm{Cl}_{2}$ solution of the complex at $-20{ }^{\circ} \mathrm{C}$.

The structure of $\mathbf{2}^{+}$is distorted octahedral (Fig. 3) with $\mathrm{N}(1)-\mathrm{Mn}-\mathrm{N}(2), \quad \mathrm{N}(2)-\mathrm{Mn}-\mathrm{N}(3)$ and $\mathrm{N}(1)-\mathrm{Mn}-\mathrm{N}(3)$ angles of $80.2(2), 90.3(2)$ and $82.0(2)^{\circ}$ respectively. The tridentate tris(3,5-dimethylpyrazolyl)methane ligand facially caps three coordination sites of the octahedral manganese. The pyrazolyl ring trans to the phosphine is closer to the metal centre than the pyrazolyl rings trans to carbonyls, with an $\mathrm{Mn}-\mathrm{N}(1)$ bond length of 2.064(5) A compared to 2.129(5) and 2.110(5) $\AA$ for $\mathrm{Mn}-\mathrm{N}(2)$ and $\mathrm{Mn}-\mathrm{N}(3)$.

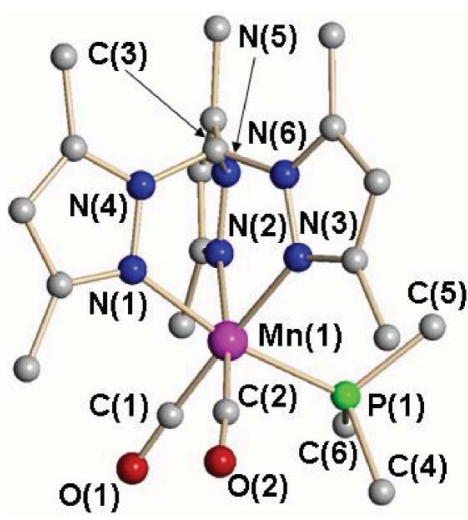

Fig. 3 The structure of $\left[\mathrm{Mn}(\mathrm{CO})_{2}\left(\mathrm{PMe}_{3}\right)\left\{\mathrm{HC}\left(\mathrm{pz}^{\prime}\right)_{3}\right\}\right]^{+} \mathbf{2}^{+}$. The hydrogen atoms have been omitted for clarity.

The related pyrazolylborate complex $\left[\mathrm{Mn}(\mathrm{CO})_{2}\left\{\mathrm{P}(\mathrm{OMe})_{3}\right\} \mathrm{Tp}^{\prime}\right]$ crystallises with two independent molecules in the unit cell and has $\mathrm{N}(1)-\mathrm{Mn}-\mathrm{N}(2), \mathrm{N}(2)-\mathrm{Mn}-\mathrm{N}(3)$ and $\mathrm{N}(1)-\mathrm{Mn}-\mathrm{N}(3)$ angles of 84.1(1), 85.3(1) and $93.5(1)^{\circ}$ and $84.3(1), 83.0(1)$ and $90.9(1)^{\circ}$ respectively. ${ }^{29}$ In one of the molecules, the pyrazolyl ring trans to the phosphite is closer to the metal centre than the pyrazolyl rings trans to carbonyls with an $\mathrm{Mn}-\mathrm{N}(1)$ bond length of 2.046(2) $\AA$ compared to 2.143(3) and 2.104(3) $\AA$ for Mn-N(2) and Mn-N(3). However, in the second molecule, the bond length for $\mathrm{Mn}-\mathrm{N}(1)$ $\{2.106(2) \AA\}$ lies between the bond lengths for $\mathrm{Mn}-\mathrm{N}(2)$ and $\mathrm{Mn}-$ $\mathrm{N}(3)\{2.078(3)$ and 2.161(3) $\AA$.

The structure of $\mathbf{6}^{+}$shows the same general features as that of $\mathbf{2}^{+}$ in that it is also distorted octahedral (Fig. 4) with a facially capping tris(3,5-dimethylpyrazolyl)methane ligand. Again, the pyrazolyl ring trans to pyridine is closer to the metal centre than the pyrazolyl rings trans to carbonyls, with an $\mathrm{Mn}-\mathrm{N}$ (1) bond length of 2.052(4) $\AA$ compared to $\mathrm{Mn}-\mathrm{N}(2)$ and $\mathrm{Mn}-\mathrm{N}$ (3) bond lengths of 2.079(4) and 2.072(4) Å respectively. In addition, the $\mathrm{Mn}-\mathrm{N}_{\text {(pyrazolyl) }}$ bond lengths for $\mathbf{6}^{+}\{2.052(4), 2.079(4)$ and 2.072(4) $\AA\}$ are slightly shorter (and more similar) than for $\mathbf{2}^{+}\{2.064(5), 2.129(5)$ and $2.110(5) \AA$.

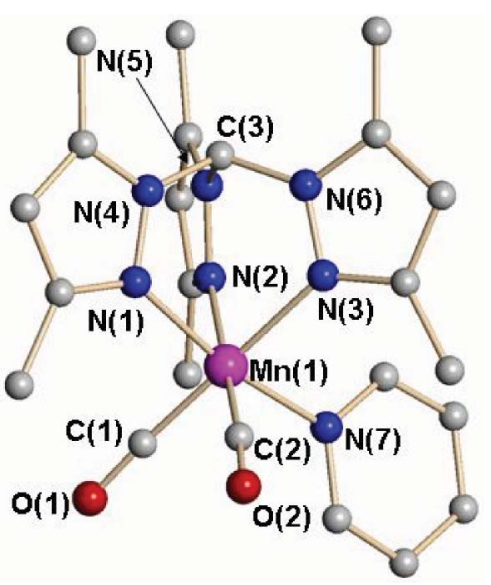

Fig. 4 The structure of $\left[\mathrm{Mn}(\mathrm{CO})_{2}(\mathrm{py})\left\{\mathrm{HC}\left(\mathrm{pz}^{\prime}\right)_{3}\right\}\right]^{+} \mathbf{6}^{+}$. The hydrogen atoms, have been omitted for clarity.

\section{Electrochemical studies}

The cyclic voltammograms in $\mathrm{CH}_{2} \mathrm{Cl}_{2}$ of the complexes $\left[\mathrm{Mn}(\mathrm{CO})_{2} \mathrm{~L}\left\{\mathrm{HC}\left(\mathrm{pz}^{\prime}\right)_{3}\right\}\right]^{+}\left\{\mathrm{L}=\mathrm{CO} \mathbf{1}^{+}, \mathrm{PMe}_{3} \mathbf{2}^{+}, \mathrm{PEt}_{3} \mathbf{3}^{+}, \mathrm{P}(\mathrm{OEt})_{3}\right.$

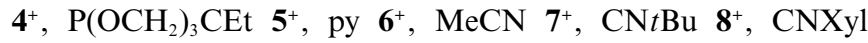
$\mathbf{9}^{+}$and $\left[\left\{\mathrm{HC}\left(\mathrm{pz}^{\prime}\right)_{3}\right\}(\mathrm{CO})_{2} \mathrm{Mn}(\mu-4,4-\text { bipy }) \mathrm{Mn}(\mathrm{CO})_{2}\left\{\mathrm{HC}\left(\mathrm{pz}^{\prime}\right)_{3}\right\}\right]^{2+}$ $\mathbf{1 0}^{2+}$ each show an irreversible oxidation wave in the potential range 0.13 to $1.11 \mathrm{~V}$ (Table 5). Complex $\mathbf{1 0}^{2+}$ also shows a partially reversible reduction at $-1.35 \mathrm{~V}\left\{I_{\text {(red) }} / I_{(\mathrm{ox})}=0.84\right.$ at a scan rate of $\left.200 \mathrm{mV} \mathrm{s}^{-1}\right\}$ (Fig. 5). Given that all of the complexes $\mathbf{2}^{+}-\mathbf{9}^{+}$are yellow or orange, the purple colour of $\mathbf{1 0}^{2+}$ suggests electron-transfer processes which must differ from those of the mononuclear complexes. Intervalence charge transfer should result in two oxidation waves in the cyclic voltammogram where only one is observed. However, given an irreversible oxidation, it is possible that decomposition occurs before a second oxidation is observed.

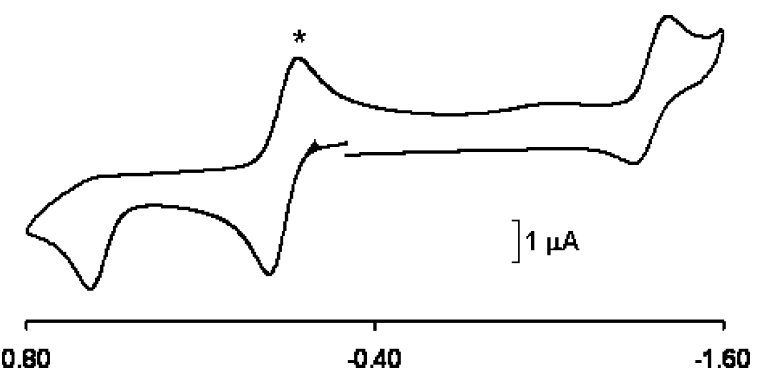

Fig. 5 Cyclic voltammogram of $\left[\left\{\mathrm{HC}_{(\mathrm{pz}}\right)_{3}\right\} \mathrm{Mn}(\mathrm{CO})_{2}\left(4,4^{\prime}\right.$-bipy)$\left.\mathrm{Mn}(\mathrm{CO})_{2}\left\{\mathrm{HC}\left(\mathrm{pz}^{\prime}\right)_{3}\right\}\right]^{2+} \mathbf{1 0}^{2+}$ in $\mathrm{CH}_{2} \mathrm{Cl}_{2}$ at a platinum electrode $\left(*\right.$ oxidation wave of $\left[\mathrm{FeCp}_{2}\right]$ calibrated to $\left.0.0 \mathrm{~V}\right)$.

As reflected in the IR spectra with decreasing $v(\mathrm{CO})$ for stronger donors, the increase in electron density at the metal results in lower oxidation potentials (i.e. there is a direct between the carbonyl stretching frequencies and the oxidation potential). A plot of $E^{0 \prime}$ against the average carbonyl stretching frequency for $\left[\mathrm{Mn}(\mathrm{CO})_{2} \mathrm{~L}\left(\eta^{5}-\mathrm{C}_{5} \mathrm{H}_{5-n} \mathrm{Me}_{n}\right)\right]$ is linear. ${ }^{15}$ As the oxidations of $\mathbf{1}^{+}-$ $\mathbf{1 0}^{2+}$ are irreversible, $E^{0}$ values were estimated from the peak potentials (assuming fully reversible systems and approximated by comparison with the peak to peak separation of the ferrocene calibrant). The plot of $v(\mathrm{CO})_{\text {ave }}$ against the estimated $E^{0}$ values for 
the tris(3,5-dimethylpyrazolyl)methane complexes described here is also linear and coincident with that for the cyclopentadienyl series $\left(\mathrm{R}^{2}=0.99\right)$ (Fig. 6). However, the data points for the acetonitrile complexes $\left[\mathrm{Mn}(\mathrm{CO})_{2}(\mathrm{NCMe})\left\{\mathrm{HC}\left(\mathrm{pz}^{\prime}\right)_{3}\right\}\right]^{+} 7^{+}$(shown in pink) and $\left[\mathrm{Mn}(\mathrm{CO})_{2}(\mathrm{NCMe})\left(\eta^{5}-\mathrm{C}_{5} \mathrm{H}_{4} \mathrm{Me}\right)\right]$ (green), the pyridine complex $\left[\mathrm{Mn}(\mathrm{CO})_{2}(\mathrm{py})\left\{\mathrm{HC}\left(\mathrm{pz}^{\prime}\right)_{3}\right\}\right]^{+} \mathbf{6}^{+}$(orange) and bimetallic $\left[\left\{\mathrm{HC}\left(\mathrm{pz}^{\prime}\right)_{3}\right\}(\mathrm{CO})_{2} \mathrm{Mn}\left(\mu-4,4^{\prime} \text {-bipy }\right) \mathrm{Mn}(\mathrm{CO})_{2}\left\{\mathrm{HC}\left(\mathrm{pz}^{\prime}\right)_{3}\right\}\right]^{2+} \mathbf{1 0}^{2+}$ (purple) do not lie on the same line. DFT studies reveal subtle differences in the HOMO which explain the different behaviour of the complexes of $N$ - and $P$-donors (see below).

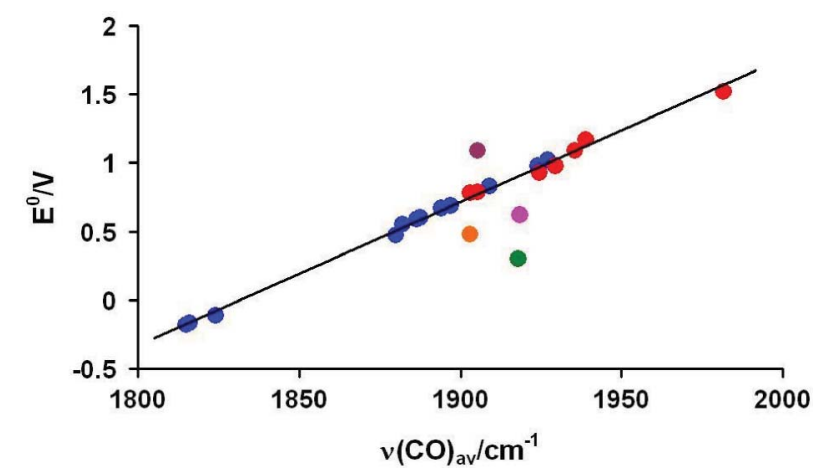

Fig. 6 A plot of $E^{0 \prime}$ against $v(\mathrm{CO})_{\text {ave }}$ for $\left[\mathrm{Mn}(\mathrm{CO})_{3-m} \mathrm{~L}_{m}\left(\eta^{5}-\mathrm{C}_{5} \mathrm{H}_{5-n} \mathrm{Me}_{n}\right)\right]$ $\left(n=0,1\right.$ or $5 ; m=1$ or 2) (blue) and $\left[\mathrm{Mn}(\mathrm{CO})_{2} \mathrm{~L}\left\{\mathrm{HC}\left(\mathrm{pz}^{\prime}\right)_{3}\right\}\right]\left[\mathrm{PF}_{6}\right]$ (red).

\section{Density Functional Theory calculations}

In an attempt to elucidate further the nature of the bonding within this series of complexes, density functional theory (DFT) calculations (computed using the B3PW91 hybrid functional) were undertaken on the phosphine complex $\mathbf{2}^{+}$, the pyridine complex $\mathbf{6}^{+}$and the 4,4'-bipyridine bridged complex $\mathbf{1 0}^{2+}$.

Firstly, the predicted lowest energy conformations of $\mathbf{2}^{+}$and $\mathbf{6}^{+}$ are similar to that observed experimentally. In both complexes, the pyrazolyl ring trans to $\mathrm{L}$ is closer to $\mathrm{Mn}\left\{2.057 \AA\right.$ for $\mathbf{2}^{+} ; 2.045$ for $\mathbf{6}^{+} \AA$ \} than the pyrazolyl rings trans to carbonyls ( 2.153 and $2.126 \AA$ for $\mathbf{2}^{+} ; 2.089$ and $2.089 \AA$ for $\mathbf{6}^{+}$). In addition, the Mn$\mathrm{N}_{\text {(pyrazolyl) }}$ bond lengths for $\mathbf{6}^{+}$are shorter (and more similar) than for $\mathbf{2}^{+}$as seen experimentally.

Although absolute values for stretching frequencies within the complexes cannot be reliably determined, relative values can be obtained. In order to determine the reasons for complexes of $\mathrm{N}$ donor ligands not conforming to the expected trend, theoretical carbonyl stretching frequencies were determined for each complex. The average calculated value for $\mathbf{2}^{+}\left(1981\right.$ and $\left.2038 \mathrm{~cm}^{-1}\right)$ is $8 \mathrm{~cm}^{-1}$ lower than that for $\mathbf{6}^{+}\left(1989\right.$ and $\left.2045 \mathrm{~cm}^{-1}\right)$. However, this is not in accord with the experimental values in which the average $\mathrm{CO}$ stretching frequency of $\mathbf{2}^{+}$is $3 \mathrm{~cm}^{-1}$ higher than that of $\mathbf{6}^{+}$.

An analysis of the frontier orbitals provides a qualitative insight into the bonding characteristics of each complex (Fig. 7). For the pyridine complex, $6^{+}$, the HOMO $(E=-7.86 \mathrm{eV})$ is mainly a $\pi$ orbital between the metal and the CO ligands (backbonding). There is also orbital coverage on the pyridine ligand. However, there is a node (and resultant phase change) between the metal and the $N$-donor. Therefore, the HOMO does not contain any M$\mathrm{N}$ bonding character. For the phosphine complex, $\mathbf{2}^{+}$, the HOMO $(E=-8.11 \mathrm{eV})$ is again mostly a $\pi$ orbital situated on manganese a)
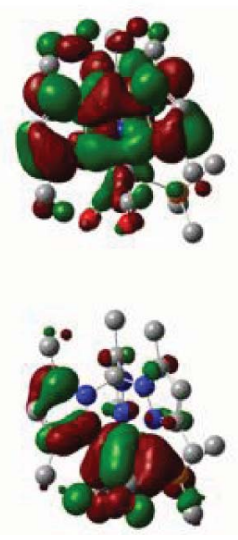

LUMO

b)

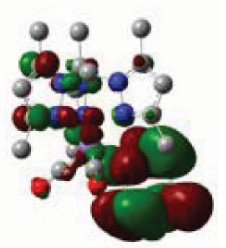

HOMO



Fig. 7 The frontier orbitals of a) $2^{+}$and b) $6^{+}$.

and the $\mathrm{CO}$ ligands. However, the HOMO also located over the $\mathrm{M}-\mathrm{P}$ bond with no node (or phase change). The contiguous nature of the HOMO results in an association between the $\mathrm{M}-\mathrm{CO}$ and $\mathrm{M}-\mathrm{P}$ bonds. These intimately entwined molecular orbitals could explain the correlation between $\mathrm{CO}$ stretching energies and the oxidation potentials of the complexes of phosphine ligands. The node (and resultant phase change) between the metal and $N$-donor ligands results in a different relationship with the $\mathrm{CO}$ ligands and, therefore, offers a possible explanation for why the plot of average $\mathrm{CO}$ stretching frequency $v s$. oxidation potential does not lie on the line of phosphine complexes.

It is noteworthy that for $\mathbf{2}^{+}$, two of the lowest unoccupied orbitals are sufficiently close in energy to be considered isoenergetic $(\Delta E<0.2 \mathrm{eV})$. The LUMO $(E=-3.78 \mathrm{eV})$ \{and LUMO $+1(E=-3.65 \mathrm{eV})\}$ are situated primarily on the tris $(3,5-$ dimethylpyrazolyl)methane ligand. By contrast, for $\mathbf{6}^{+}$the LUMO $(E=-4.00 \mathrm{eV})$ is situated primarily on the pyridine ligand. The frontier orbitals of $\mathbf{1 0}^{2+}$ are similar in location to the pyridine complex $6^{+}$(Fig. 8). The HOMO (-9.14 eV) and HOMO-1

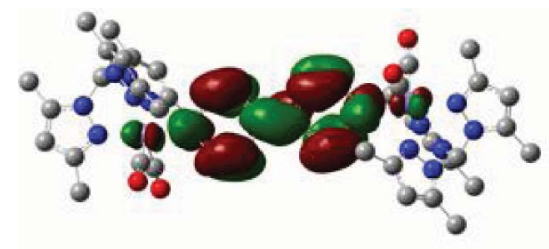

LUMO

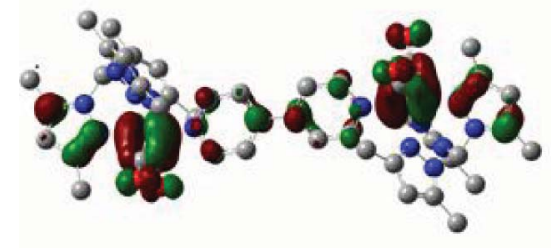

HOMO

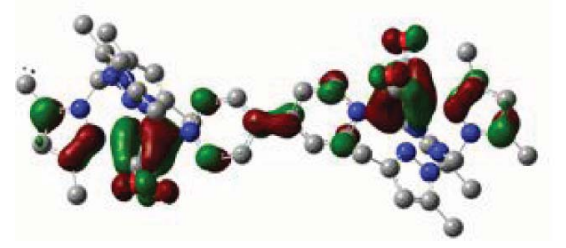

HOMO - 1

Fig. 8 Graphical representation of the frontier orbitals for $\mathbf{1 0}^{2+}$. 
$(-9.31 \mathrm{eV})$ can be considered isoenergetic and are lower than for $\mathbf{6}^{+}$. This results in greater stabilisation of the complex and an increase in oxidation potential, as seen experimentally. Both orbitals are situated on the manganese metal centres and $\mathrm{CO}$ ligands with some electron density on the 4-position of the 4,4'-bipyridine ligand. There is again a node (and phase change) between the metal and the $N$-donor ligands as observed in the monometallic complex. The LUMO is situated almost entirely on the 4,4'-bipyridine ligand. The location of the frontier orbitals (and the purple colour of the complex) suggest that an MLCT transition is occurring. The HOMO-LUMO bandgap for $\mathbf{1 0}^{2+}\left(E_{\text {bandgap }}=2.67 \mathrm{eV}\right)$ is much smaller than for $\mathbf{2}^{+}\left(E_{\text {bandgap }}=4.33 \mathrm{eV}\right)$ or $\mathbf{6}^{+}\left(E_{\text {bandgap }}=3.86 \mathrm{eV}\right)$. This results in the lowest energy absorption (464 nm $c f .287$ and $321 \mathrm{~nm}$ for $\mathbf{2}^{+}$and $\mathbf{6}^{+}$respectively) falling into the visible region giving a possible explanation for the observed colour. Interestingly, rotation about the $4,4^{\prime}$-position of the bipyridine ligand of $28^{\circ}$ from planarity gives the lowest energy configuration.

\section{Conclusions}

The first examples of manganese dicarbonyl complexes bearing a neutral pyrazolylmethane ligand, $\left[\mathbf{M n}(\mathbf{C O})_{2} \mathbf{L}\left\{\mathbf{H C}\left(\mathbf{p z}^{\prime}\right)_{3}\right\}\right]\left[\mathbf{P F}_{6}\right]$, were prepared from the parent tricarbonyl using $\mathrm{Me}_{3} \mathrm{NO}$ in the presence of co-ordinating lignds. X-ray crystallography has shown that similar structures are adopted for complexes with $P$ - and $N$ donor ligands. Pyrazolyl rings trans to these ligands are closer to the metal than those trans to carbonyls. Pyrazolyl rings are slightly closer to the metal (and more similar) for the pyridine complex compared to the phosphine complex.

There is a direct correlation between the average carbonyl stretching frequency and the oxidation potential for complexes of $P$-donor ligands. A plot of $v(\mathrm{CO})_{\text {ave }} v s . E^{0 \prime}$ is linear and coincident with the correlation observed for $\left[\mathrm{Mn}(\mathrm{CO})_{3-m} \mathrm{~L}_{m}\left(\eta-\mathrm{C}_{5} \mathrm{H}_{5-n} \mathrm{Me}_{n}\right)\right]$. The data for $N$-donor ligands do not lie on this line. A possible explanation is offered by DFT analysis of $\mathbf{2}^{+}, \mathbf{6}^{+}$and $\mathbf{1 0}^{2+}$ which shows the contiguous HOMO located over the M-CO and the $\mathrm{M}$-P bonds for the $P$-donor whereas a node exists between the metal and $N$-donors.

Reaction of $\left[\mathrm{Mn}(\mathrm{CO})_{2}(\mathrm{NCMe})\left\{\mathrm{HC}\left(\mathrm{pz}^{\prime}\right)_{3}\right\}\right]^{+}$with half an equivalent of 4,4'-bipyridine, yields a purple compound assumed to be $\left[\left\{\mathrm{HC}\left(\mathrm{pz}^{\prime}\right)_{3}\right\}(\mathrm{CO})_{2} \mathrm{Mn}\left(\mu-4,4^{\prime} \text {-bipy }\right) \mathrm{Mn}(\mathrm{CO})_{2}\left\{\mathrm{HC}\left(\mathrm{pz}^{\prime}\right)_{3}\right\}\right]^{2+}$. The smaller HOMO-LUMO bandgap compared with the mononuclear complexes results in lower energy absorptions and a possible explanation for the colour of the complex, as determined by DFT studies.

\section{Experimental}

The preparation, purification and reactions of the complexes described were carried out using Schlenk techniques under an atmosphere of dry nitrogen using solvents dried by Anhydrous Engineering double alumina or alumina/copper catalyst columns. All solvents were deoxygenated prior to use unless otherwise stated. The compounds $\left[\mathrm{MnBr}(\mathrm{CO})_{5}\right]^{30}$ and $\mathrm{HC}\left(\mathrm{pz}^{\prime}\right)_{3}{ }^{8,31}$ were prepared by published methods.

X-Ray diffraction studies were performed on a Siemens threecircle SMART area diffractometer. All calculations were made with programmes of the SHELXTL system. ${ }^{32}$
DFT studies were performed using the Gaussian 03 suite of programs. ${ }^{33}$ Calculations were carried out with the hybrid B3PW91 functional, with the 6-31G(d,p) basis set for manganese and the coordinating atoms and 6-31G basis set for all other atoms. Geometry optimisations were performed without restraints, followed by frequency calculations to ascertain the nature of the resulting structure (minimum $v s$. transition state).

NMR spectra were recorded on a JEOL GX270 or JEOL $\lambda 300$ spectrometer with $\mathrm{SiMe}_{4}$ as an internal standard. ${ }^{31} \mathrm{P}$ NMR spectra were recorded at $121 \mathrm{MHz}$.

Electrochemical studies were carried out using an EG\&G model 273A potentiostat linked to a computer using EG\&G Model 270 Research Electrochemistry software in conjunction with a threeelectrode cell. The auxiliary electrode was a platinum wire and the working electrode a platinum disc (1.6 $\mathrm{mm}$ diameter). The reference was an aqueous saturated calomel electrode separated from the test solution by a fine porosity frit and an agar bridge saturated with $\mathrm{KCl}$. Solutions were $1.0 \times 10^{-3} \mathrm{~mol} \mathrm{dm}^{-3}$ in the test

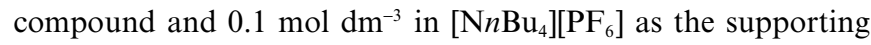
electrolyte. The solvent used was $\mathrm{CH}_{2} \mathrm{Cl}_{2}$. Data are calibrated using $\left[\mathrm{Fe}\left(\eta^{5}-\mathrm{C}_{5} \mathrm{H}_{5}\right)_{2}\right]$ or $\left[\mathrm{Fe}\left(\eta^{5}-\mathrm{C}_{5} \mathrm{Me}_{5}\right)_{2}\right]$ added to the test solutions as an internal calibrant. Under these conditions, $E^{0 \prime}$ for the one-electron oxidation of $\left[\mathrm{Fe}\left(\eta-\mathrm{C}_{5} \mathrm{H}_{5}\right)_{2}\right]$ and $\left[\mathrm{Fe}\left(\eta^{5}-\mathrm{C}_{5} \mathrm{Me}_{5}\right)_{2}\right]$ is set to 0.00 and $-0.55 \mathrm{~V}$ respectively. Unless specified, all electrochemical values are at a scan rate of $200 \mathrm{mVs}^{-1}$.

Microanalyses were carried out by the staff of the Microanalytical Service of the School of Chemistry, University of Bristol.

\section{Synthesis}

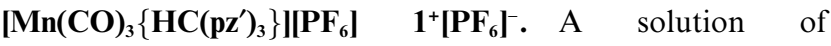
$\left[\mathrm{MnBr}(\mathrm{CO})_{5}\right](1.36 \mathrm{~g}, 4.96 \mathrm{mmol})$ and $\mathrm{HC}\left(\mathrm{pz}^{\prime}\right)_{3}(1.509 \mathrm{~g}$, $5.06 \mathrm{mmol})$ in toluene $\left(75 \mathrm{~cm}^{3}\right)$ was heated under reflux for $2 \mathrm{~h}$ during which time a yellow precipitate was formed. The mixture was allowed to reach room temperature and the pale yellow mother liquors decanted. The yellow powder was dissolved in water $\left(60 \mathrm{~cm}^{3}\right)$ and then $\left[\mathrm{NH}_{4}\right]\left[\mathrm{PF}_{6}\right](825 \mathrm{mg}, 5.06 \mathrm{mmol})$ was added to precipitate a pale yellow solid. The mixture was stirred for $1 \mathrm{~h}$ and the precipitate collected. The yellow powder was washed with water $\left(2 \times 30 \mathrm{~cm}^{3}\right)$ and then dried in vacuo, yield $2.31 \mathrm{~g}(80 \%) .{ }^{1} \mathrm{H}$ NMR $\left(270 \mathrm{MHz}, \mathrm{CD}_{2} \mathrm{Cl}_{2}\right) \delta_{\mathrm{H}}=7.79\{1 \mathrm{H}, \mathrm{s}$, $\left.H \mathrm{C}\left(\mathrm{pz}^{\prime}\right)_{3}\right\}, 6.18(3 \mathrm{H}, \mathrm{s}, \mathrm{PzCH}), 2.59\left(9 \mathrm{H}, \mathrm{s}, \mathrm{PzCH}_{3}\right), 2.58(9 \mathrm{H}, \mathrm{s}$, $\left.\mathrm{PzCH}_{3}\right) \mathrm{ppm}$.

General procedure for the synthesis of $\left[\mathrm{Mn}(\mathrm{CO})_{2} \mathrm{~L}\right.$ $\left.\left\{\mathbf{H C}\left(\mathbf{p z}^{\prime}\right)_{3}\right\}\right]\left[\mathbf{P F}_{\mathbf{6}} \mathbf{l} \mathbf{3}^{+} \mathbf{6}^{+}\right.$and $\mathbf{8}^{+}-\mathbf{9}^{+}$. Solid $\mathrm{Me}_{3} \mathrm{NO}(18 \mathrm{mg}$, $0.240 \mathrm{mmol})$ was added to a solution of $\left[\mathrm{Mn}(\mathrm{CO})_{3}\left\{\mathrm{HC}\left(\mathrm{pz}^{\prime}\right)_{3}\right\}\right]-$ $\left[\mathrm{PF}_{6}\right](140 \mathrm{mg}, 0.240 \mathrm{mmol})$ and $\mathrm{L}$ (1 equiv.) in $\mathrm{CH}_{2} \mathrm{Cl}_{2}\left(20 \mathrm{~cm}^{3}\right)$ and the mixture stirred for $10 \mathrm{~min}$. Small portions of $\mathrm{Me}_{3} \mathrm{NO}$ (ca. $1 \mathrm{mg}$ ) were added until the reaction was complete (shown by IR spectroscopy). The resulting yellow or orange solution was filtered and then concentrated in vacuo. $n$-Hexane was then added to precipitate a powder, which was washed with $n$-hexane $(2 \times$ $20 \mathrm{~cm}^{3}$ ) and dried in vacuo.

$\left[\mathbf{M n}(\mathbf{C O})_{2}\left(\mathbf{P E t}_{3}\right)\left\{\mathbf{H C}\left(\mathbf{p z}^{\prime}\right)_{3}\right\}\right]\left[\mathbf{P F}_{6}\right] \quad \mathbf{3}^{+}\left[\mathbf{P F}_{6}\right]^{-}$. Yield $144 \mathrm{mg}$ $(89 \%) .{ }^{1} \mathrm{H} \mathrm{NMR}\left(270 \mathrm{MHz}, \mathrm{CD}_{2} \mathrm{Cl}_{2}\right) \delta_{\mathrm{H}}=7.66\left\{1 \mathrm{H}, \mathrm{s}, H \mathrm{C}\left(\mathrm{pz}^{\prime}\right)_{3}\right\}$, $6.24(2 \mathrm{H}, \mathrm{s}, \mathrm{PzCH}), 5.89(1 \mathrm{H}, \mathrm{s}, \mathrm{PzCH}), 2.67\left(6 \mathrm{H}, \mathrm{s}, \mathrm{PzCH}_{3}\right)$, $2.63\left(6 \mathrm{H}, \mathrm{s}, \mathrm{PzCH}_{3}\right), 2.53\left(3 \mathrm{H}, \mathrm{s}, \mathrm{PzCH}_{3}\right), 2.39\left(3 \mathrm{H}, \mathrm{s}, \mathrm{PzCH}_{3}\right)$, 
$1.60-1.75\left\{6 \mathrm{H}, \mathrm{dq}, J_{\mathrm{H}, \mathrm{P}}=7 \mathrm{~Hz}, J_{\mathrm{H}, \mathrm{H}}=7 \mathrm{~Hz}, \mathrm{P}\left(\mathrm{CH}_{2} \mathrm{CH}_{3}\right)_{3}\right\}, 0.69$ $0.87\left\{9 \mathrm{H}, \mathrm{dt}, J_{\mathrm{H}, \mathrm{P}}=7 \mathrm{~Hz}, J_{\mathrm{H}, \mathrm{H}}=7 \mathrm{~Hz}, \mathrm{P}\left(\mathrm{CH}_{2} \mathrm{CH}_{3}\right)_{3}\right\}$ ppm.

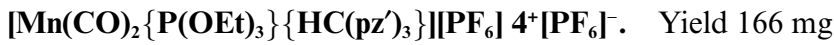
$(96 \%) .{ }^{1} \mathrm{H} \mathrm{NMR}\left(270 \mathrm{MHz}, \mathrm{CD}_{2} \mathrm{Cl}_{2}\right) \delta_{\mathrm{H}}=7.72\left\{1 \mathrm{H}, \mathrm{s}, H \mathrm{C}\left(\mathrm{pz}^{\prime}\right)_{3}\right\}$, $6.18(2 \mathrm{H}, \mathrm{s}, \mathrm{PzCH}), 5.98(1 \mathrm{H}, \mathrm{s}, \mathrm{PzCH}), 3.71\left\{6 \mathrm{H}, \mathrm{dq}, J_{\mathrm{H}, \mathrm{P}}=7 \mathrm{~Hz}\right.$, $\left.J_{\mathrm{H}, \mathrm{H}}=7 \mathrm{~Hz}, \mathrm{P}\left(\mathrm{OCH}_{2} \mathrm{CH}_{3}\right)_{3}\right\}, 2.66\left(6 \mathrm{H}, \mathrm{s}, \mathrm{PzCH}_{3}\right), 2.61(6 \mathrm{H}, \mathrm{s}$, $\left.\mathrm{PzCH}_{3}\right), 2.54\left(3 \mathrm{H}, \mathrm{s}, \mathrm{PzCH}_{3}\right), 2.45\left(3 \mathrm{H}, \mathrm{s}, \mathrm{PzCH}_{3}\right), 1.19\{9 \mathrm{H}, \mathrm{t}$, $\left.J_{\mathrm{H}, \mathrm{H}}=7 \mathrm{~Hz}, \mathrm{P}\left(\mathrm{OCH}_{2} \mathrm{CH}_{3}\right)_{3}\right\}$ ppm.

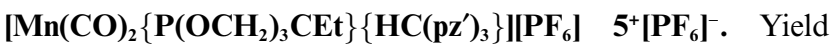
$141 \mathrm{mg}(82 \%) .{ }^{1} \mathrm{H}$ NMR $\left(270 \mathrm{MHz}, \mathrm{CD}_{2} \mathrm{Cl}_{2}\right) \delta_{\mathrm{H}}=7.60\{1 \mathrm{H}$, s, $\left.H \mathrm{C}\left(\mathrm{pz}^{\prime}\right)_{3}\right\}, 6.08(2 \mathrm{H}, \mathrm{s}, \mathrm{PzCH}), 5.95(1 \mathrm{H}, \mathrm{s}, \mathrm{PzCH}), 4.14\{6 \mathrm{H}$, br s, $\left.\mathrm{P}\left(\mathrm{OCH}_{2}\right)_{3} \mathrm{CEt}\right\}, 2.00-2.85\left(18 \mathrm{H}\right.$, br m, $\left.\mathrm{PzCH}_{3}\right), 1.15\{2 \mathrm{H}, \mathrm{s}$, $\left.\mathrm{P}\left(\mathrm{OCH}_{2}\right)_{3} \mathrm{CCH}_{2} \mathrm{CH}_{3}\right\}, 0.74\left\{3 \mathrm{H}, \mathrm{s}, \mathrm{P}\left(\mathrm{OCH}_{2}\right)_{3} \mathrm{CCH}_{2} \mathrm{CH}_{3}\right\}$ ppm.

$\left[\mathbf{M n}(\mathbf{C O})_{2}(\mathbf{p y})\left\{\mathbf{H C}\left(\mathbf{p z}^{\prime}\right)_{3}\right\}\right]\left[\mathbf{P F}_{\mathbf{6}}\right] \mathbf{6}^{+}\left[\mathbf{P F}_{\mathbf{6}}\right]^{-}$. Yield $143 \mathrm{mg}(94 \%)$. ${ }^{1} \mathrm{H}$ NMR $\left(270 \mathrm{MHz}, \mathrm{CD}_{2} \mathrm{Cl}_{2}\right) \delta_{\mathrm{H}}=8.85(1 \mathrm{H}$, br s, pyC $H), 7.95$ $\left\{1 \mathrm{H}, \mathrm{s}, H \mathrm{C}\left(\mathrm{pz}^{\prime}\right)_{3}\right\}, 7.62(1 \mathrm{H}$, br s, pyC $H), 7.33(1 \mathrm{H}, \mathrm{br} \mathrm{s}, \mathrm{pyC} H)$, $7.14(1 \mathrm{H}$, br s, pyCH), $7.00(1 \mathrm{H}$, br s, pyCH $), 6.20(2 \mathrm{H}, \mathrm{s}, \mathrm{PzCH})$, $5.89(1 \mathrm{H}, \mathrm{s}, \mathrm{PzCH}), 2.69\left(6 \mathrm{H}, \mathrm{s}, \mathrm{PzCH}_{3}\right), 2.50\left(3 \mathrm{H}, \mathrm{s}, \mathrm{PzCH}_{3}\right), 2.45$ $\left(3 \mathrm{H}, \mathrm{s}, \mathrm{PzCH}_{3}\right), 1.80\left(6 \mathrm{H}, \mathrm{s}, \mathrm{PzCH}_{3}\right) \mathrm{ppm}$.

$\left.\left[\mathbf{M n}(\mathbf{C O})_{2}\left(\mathbf{C N B u}^{\mathrm{t}}\right)\left\{\mathbf{H C}_{(\mathbf{p z}}\right)_{3}\right\}\right]\left[\mathbf{P F}_{\mathbf{6}} \mathbf{]} \mathbf{8}^{+}\left[\mathbf{P F}_{6}\right]^{-}\right.$. Yield $130 \mathrm{mg}$ $(85 \%) .{ }^{1} \mathrm{H} \mathrm{NMR}\left(270 \mathrm{MHz}, \mathrm{CD}_{2} \mathrm{Cl}_{2}\right) \delta_{\mathrm{H}}=7.72\left\{1 \mathrm{H}, \mathrm{s}, H \mathrm{C}\left(\mathrm{pz}^{\prime}\right)_{3}\right\}$, $6.14(2 \mathrm{H}, \mathrm{s}, \mathrm{PzCH}), 6.04(1 \mathrm{H}, \mathrm{s}, \mathrm{PzCH}), 2.45-2.65(18 \mathrm{H}$, br m, $\left.\mathrm{PzCH}_{3}\right), 1.48\left\{9 \mathrm{H}, \mathrm{s},\left(\mathrm{CH}_{3}\right)_{3} \mathrm{CNC}\right\}$ ppm.

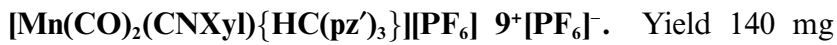
$(85 \%) .{ }^{1} \mathrm{H}$ NMR $\left(270 \mathrm{MHz}, \mathrm{CD}_{2} \mathrm{Cl}_{2}\right) \delta_{\mathrm{H}}=7.79\left\{1 \mathrm{H}, \mathrm{s}, H \mathrm{C}\left(\mathrm{pz}^{\prime}\right)_{3}\right\}$, $7.14\left(3 \mathrm{H}\right.$, br s, 2,6- $\left.\mathrm{Me}_{2} \mathrm{C}_{6} H_{3} \mathrm{NC}\right), 6.15(2 \mathrm{H}, \mathrm{s}, \mathrm{PzCH}), 6.09(1 \mathrm{H}, \mathrm{s}$, $\mathrm{PzCH}), 2.60\left(9 \mathrm{H}\right.$, br s, $\left.\mathrm{PzCH}_{3}\right), 2.55\left(9 \mathrm{H}\right.$, br s, $\left.\mathrm{PzCH}_{3}\right), 2.33\{6 \mathrm{H}$, s, 2,6- $\left.\left(\mathrm{CH}_{3}\right)_{2} \mathrm{C}_{6} \mathrm{H}_{3} \mathrm{NC}\right\}$ ppm.

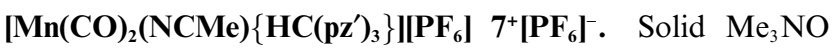
(38 $\mathrm{mg}, \quad 0.506 \mathrm{mmol}$ ) was added to a solution of

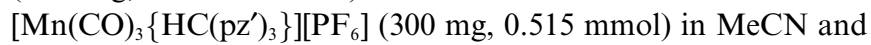
the mixture stirred for $15 \mathrm{~min}$. Small aliquots of $\mathrm{Me}_{3} \mathrm{NO}$ ( $c a$. $1 \mathrm{mg}$ ) were added until the reaction was complete. The solvent was removed in vacuo and the crude product dissolved in $\mathrm{CH}_{2} \mathrm{Cl}_{2}$ $(10 \mathrm{ml})$. The orange solution was filtered through Celite and concentrated in vacuo before $n$-hexane was added to precipitate an orange powder which was washed with $n$-hexane $\left(2 \times 20 \mathrm{~cm}^{3}\right)$ and dried in vacuo, yield $279 \mathrm{mg}(91 \%) .{ }^{1} \mathrm{H}$ NMR $(270 \mathrm{MHz}$, $\left.\mathrm{CD}_{2} \mathrm{Cl}_{2}\right) \delta_{\mathrm{H}}=7.82\left\{1 \mathrm{H}, \mathrm{s}, H \mathrm{C}\left(\mathrm{pz}^{\prime}\right)_{3}\right\}, 6.22(2 \mathrm{H}, \mathrm{s}, \mathrm{PzC} H), 5.89$ $(1 \mathrm{H}, \mathrm{s}, \mathrm{PzCH}), 2.62\left(6 \mathrm{H}, \mathrm{s}, \mathrm{PzCH}_{3}\right), 2.56\left(6 \mathrm{H}, \mathrm{s}, \mathrm{PzCH}_{3}\right), 2.47$ $\left(3 \mathrm{H}, \mathrm{s}, \mathrm{PzCH}_{3}\right), 2.39\left(3 \mathrm{H}, \mathrm{s}, \mathrm{PzCH}_{3}\right), 2.17\left(3 \mathrm{H}, \mathrm{s}, \mathrm{CH}_{3} \mathrm{CN}\right) \mathrm{ppm}$.

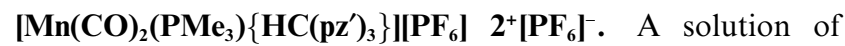
$\left[\mathrm{Mn}(\mathrm{CO})_{2}(\mathrm{NCMe})\left\{\mathrm{HC}\left(\mathrm{pz}^{\prime}\right)_{3}\right\}\right]\left[\mathrm{PF}_{6}\right](115 \mathrm{mg}, 0.193 \mathrm{mmol})$ and $\mathrm{PMe}_{3}(30 \mu \mathrm{l}, 0.289 \mathrm{mmol})$ in $\mathrm{CH}_{2} \mathrm{Cl}_{2}\left(20 \mathrm{~cm}^{3}\right)$ was stirred for $30 \mathrm{~min}$, then filtered and concentrated in vacuo. $n$-Hexane was added to precipitate a yellow solid which was washed with $n$ hexane $\left(2 \times 20 \mathrm{~cm}^{3}\right)$ and dried in vacuo, yield $116 \mathrm{mg}(95 \%) .{ }^{1} \mathrm{H}$ $\mathrm{NMR}\left(270 \mathrm{MHz}, \mathrm{CD}_{2} \mathrm{Cl}_{2}\right) \delta_{\mathrm{H}}=7.58\left\{1 \mathrm{H}, \mathrm{s}, H \mathrm{C}\left(\mathrm{pz}^{\prime}\right)_{3}\right\}, 6.14(2 \mathrm{H}$, s, $\mathrm{PzCH}), 5.82(1 \mathrm{H}, \mathrm{s}, \mathrm{PzCH}), 2.58\left(6 \mathrm{H}, \mathrm{s}, \mathrm{PzCH}_{3}\right), 2.54(6 \mathrm{H}, \mathrm{s}$, $\left.\mathrm{PzCH}_{3}\right), 2.43\left(3 \mathrm{H}, \mathrm{s}, \mathrm{PzCH}_{3}\right), 2.32\left(3 \mathrm{H}, \mathrm{s}, \mathrm{PzCH}_{3}\right), 1.23\{9 \mathrm{H}, \mathrm{d}$, $\left.J_{\mathrm{H}, \mathrm{P}}=8 \mathrm{~Hz}, \mathrm{P}\left(\mathrm{CH}_{3}\right)_{3}\right\}$ ppm.

$\left[\left\{\mathrm{HC}_{(\mathbf{p z}}\right)_{3}\right\}(\mathrm{CO})_{2} \mathrm{Mn}\left(\boldsymbol{\mu}-\mathbf{4}, \mathbf{4}^{\prime}\right.$-bipy $\left.) \mathrm{Mn}(\mathrm{CO})_{2}\left\{\mathrm{HC}\left(\mathrm{pz}^{\prime}\right)_{3}\right\}\right]\left[\mathrm{PF}_{6}\right]_{2}$ $\mathbf{1 0}^{2+} \mathbf{2}\left[\mathbf{P F}_{6} \mathbf{l}^{-}\right.$. A solution of $\left[\mathrm{Mn}(\mathrm{CO})_{2}(\mathrm{NCMe})\left\{\mathrm{HC}\left(\mathrm{pz}^{\prime}\right)_{3}\right\}\right]\left[\mathrm{PF}_{6}\right]$ (126 mg, $0.212 \mathrm{mmol}$ ) and 4,4'-bipyridine (17 mg, $0.109 \mathrm{mmol})$ in $\mathrm{CH}_{2} \mathrm{Cl}_{2}\left(20 \mathrm{~cm}^{3}\right)$ was stirred for $45 \mathrm{~min}$, then filtered and concentrated in vacuo. $n$-Hexane was added to precipitate a purple solid which was washed with $n$-hexane $\left(2 \times 20 \mathrm{~cm}^{3}\right)$ and dried in vacuo, yield $110 \mathrm{mg}(82 \%)$.

\section{Acknowledgements}

We thank the EPSRC (R.A.B) and the School of Chemistry, University of Bristol (A.J.H.) for Postgraduate Scholarships. Prof. N. G. Connelly (University of Bristol) is also gratefully acknowledged.

\section{Notes and references}

1 H. R. Bigmore, S. C. Lawrence, P. Mountford and C. S. Tredget, Dalton Trans., 2005, 635

2 M. G. Cushion and P. Mountford, Chem. Commun., 2011, 47, 2276.

3 S. Trofimenko, Chem. Rev., 1993, 93, 943.

4 S. Trofimenko, Scorpionates: The Co-ordination Chemistry of Polypyrazolylborate LigandsImperial College Press: London, 1999.

5 C. Pettinari and C. Santini, Polypyrazolylborate and Scorpionate Ligands; In J. A. McClevery and T. H. Meyer, ed., Comprehensive Co-ordination Chemistry II -From Biology to NanotechnologyElsevier Ltd: Oxford, U. K, 2004; Vol. 1, pp 159-210.

6 C. Pettinari and R. Pettinari, Coord. Chem. Rev., 2005, 249, 525 and references therein.

7 A. F. R. Kilpatrick, S. V. Kulangara, M. G. Cushion, R. Duchateau and P. Mountford, Dalton Trans., 2010, 39, 3653.

8 D. L. Reger, T. C. Grattan, K. J. Brown, C. A. Little, J. J. S. Lamba, A. L. Rheingold and R. D. Sommer, J. Organomet. Chem., 2000, 607, 120.

9 Z. Pang, T. J. Burkey and R. F. Johnson, Organometallics, 1997, 16, 120.

10 P. C. Kunz, W. Huber, A. Rojas, U. Schatzschneider and B. Spingler, Eur. J. Inorg. Chem., 2009, 5358.

11 J. Niesel, A. Pinto, H. W. Peindy N'Dongo, K. Merz, I. Ott, R. Gust and U. Schatzschneider, Chem. Commun., 2008, 1798.

12 H. Pfeiffer, A. Rojas, J. Niesel and U. Schatzschneider, Dalton Trans., 2009, 4292.

13 D. L. Reger, R. F. Semeniuc and M. D. Smith, J. Organomet. Chem., 2003, 666, 87

14 A. R. Schoenberg and W. P. Anderson, Inorg. Chem., 1974, 13, 465.

15 N. G. Connelly and M. D. Kitchen, J. Chem. Soc., Dalton Trans., 1977, 931.

16 O. Kaufhold, A. Stasch, P. G. Edwards and F. E. Hahn, Chem. Commun., 2007, 1822.

17 O. Kaufhold, A. Stasch, T. Pape, A. Hepp, P. G. Edwards, P. D. Newman and F. E. Hahn, J. Am. Chem. Soc., 2009, 131, 307.

18 S. Trofimenko, J. Am. Chem. Soc., 1970, 92, 5118.

19 D. L. Reger, R. F. Semeniuc and M. D. Smith, J. Chem. Soc., Dalton Trans., 2002, 476.

20 D. L. Reger, J. R. Gardinier, T. C. Grattan and M. D. Smith, J. Organomet. Chem., 2005, 690, 1901.

21 A. R. Schoenberg and W. P. Anderson, Inorg. Chem., 1972, 11, 85.

22 D. L. Reger, K. J. Brown and M. D. Smith, J. Organomet. Chem., 2002, 658, 50 .

23 C. A. Streuli, Anal. Chem., 1960, 32, 985.

24 E. M. Thorsteinson and F. Basolo, J. Am. Chem. Soc., 1966, 88, 3929.

25 W. A. G. Graham, Inorg. Chem., 1968, 7, 315.

26 D. M. Tellers, S. J. Skoog, R. G. Bergman, T. B. Gunnoe and W. D. Harman, Organometallics, 2000, 19, 2428 and references therein.

27 K. Fujisawa, T. Ono, Y. Ishikawa, N. Amir, Y. Miyashita, K. Okamoto and N. Lehnert, Inorg. Chem., 2006, 45, 1698.

28 R. B. King and A. J. Efraty, J. Am. Chem. Soc., 1972, 94, 3773.

29 J. E. Joachim, C. Apostolidis, B. Kanellakopulos, D. Meyer, B. Nuber, K. Raptis, J. Rebizant and M. L. Ziegler, J. Organomet. Chem., 1995, 492, 199.

30 E. W. Abel and G. Wilkinson, J. Chem. Soc., 1959, 1501.

31 A. J. Hallett, K. M. Anderson, N. G. Connelly and M. F. Haddow, Dalton Trans., 2009, 4181.

32 SHELXTS-PC Package, Bruker Analytical X-ray Systems, Madison WI, 1998

33 M. J. Frisch, G. W. Trucks, H. B. Schlegel, G. E. Scuseria, M. A. Robb, J. R. Cheeseman, J. A. Montgomery, Jr., T. Vreven, K. N. 
Kudin, J. C. Burant, J. M. Millam, S. S. Iyengar, J. Tomasi, V. Barone, B. Mennucci, M. Cossi, G. Scalmani, N. Rega, G. A. Petersson, H. Nakatsuji, M. Hada, M. Ehara, K. Toyota, R. Fukuda, J. Hasegawa, M. Ishida, T. Nakajima, Y. Honda, O. Kitao, H. Nakai, M. Klene, X Li, J. E. Knox, H. P. Hratchian, J. B. Cross, V. Bakken, C. Adamo, J. Jaramillo, R. Gomperts, R. E. Stratmann, O. Yazyev, A. J. Austin, R. Cammi, C. Pomelli, J. Ochterski, P. Y. Ayala, K. Morokuma, G. A. Voth, P. Salvador, J. J. Dannenberg, V. G. Zakrzewski, S. Dapprich,
A. D. Daniels, M. C. Strain, O. Farkas, D. K. Malick, A. D. Rabuck, K. Raghavachari, J. B. Foresman, J. V. Ortiz, Q. Cui, A. G. Baboul, S. Clifford, J. Cioslowski, B. B. Stefanov, G. Liu, A. Liashenko, P. Piskorz, I. Komaromi, R. L. Martin, D. J. Fox, T. Keith, M. A. AlLaham, C. Y. Peng, A. Nanayakkara, M. Challacombe, P. M. W. Gill, B. G. Johnson, W. Chen, M. W. Wong, C. Gonzalez and J. A. Pople, GAUSSIAN 03 (Revision B.03), Gaussian, Inc., Wallingford, CT, 2004. 